\title{
The Influence of Ceo Turnover and Committee Audit Characteristic Toward Audit Fees
}

\author{
Shabrina Herawati and Yustrida Bernawati \\ ${ }^{1}$ Department of Accounting, Faculty of Economic \& Business, Airlangga University, Surabaya, \\ Email address: \\ *brina.serenade@gmail.com; yustridabernawati@yahoo.com \\ ${ }^{*}$ Corresponding author
}

\begin{abstract}
This study aims to test empirically the effect of CEO turnover and the frequency of audit committee meetings on external audit fees. The population of this research is all manufacturing companies listed on the IDX in 2018-2019. By using the purposive sampling technique, obtained a sample of 103 companies in 2 years. This study uses secondary data in the form of annual reports where data is obtained from the IDX or the Company's website. Hypothesis testing uses quantitative methods with multiple regression analysis techniques. To test the impact to make it more credible, control variables are used, namely Return On Assets (ROA) and Total Assets. The results of hypothesis testing show that CEO turnover and audit committee meeting frequency do not affect audit fees. Meanwhile, ROA and total assets have a significant positive effect on external audit fees.
\end{abstract}

Keywords: CEO Change, Audit Committee, ROA, Total Asset, Audit fees

Abstrak: Penelitian ini bertujuan untuk menguji secara empiris pengaruh pergantian CEO dan frekuensi pertemuan komite audit terhadap fee audit eksternal. Populasi penelitian ini adalah seluruh perusahaan manufaktur yang terdaftar di BEI tahun 2018-2019. Menggunakan teknik purposive sampling, diperoleh sampel sebanyak 103 perusahaan dalam 2 tahun. Penelitian ini menggunakan data sekunder dalam bentuk laporan tahunan dimana data diperoleh dari BEI maupun dari website resmi Perusahaan. Pengujian hipotesis menggunakan metode kuantitatif dengan teknik analisis regresi berganda. Untuk melakukan pengujian yang lebih kredibel, digunakan variabel kontrol, yaitu Return On Assets (ROA) dan Total Aset. Hasil dari pengujian hipotesis menunjukkan bahwa pergantian CEO dan frekuensi pertemuan komite audit tidak berpengaruh terhadap fee audit. Sementara itu, ROA dan Total Aset memiliki pengaruh positif signifikan terhadap fee audit.

Kata Kunci: Pergantian CEO, Komite Audit, ROA, Total Aset, Fee Audit

\section{INTRODUCTION}

Financial statements are important document which is containing company's important information. Financial statements help stakeholder to make various decisions. In terms of increasing stakeholder's trust over the company's financial statements, public company is obligated to audit its financial statements (Chandra, 2016). While accepting audit 
engagement, the company has three risks that are (1) client's business risk which related to profitability and client's survival; 2) audit risk which means that there is possibility that the client misstated the financial statement and the auditor fails to recognize the misstatement; 3 ) auditor of business risk which is related to litigation potential cost and the potential of reputation effect is harmful (Huang et al., 2014).

Unfortunately, some cases show that corporate governance is weak as it appears on some Indonesian companies. As shown in PT. Jiwasraya's case in which the management claimed that the company gained profit of 360 billion rupiahs, but in fact the company lost 7 trillion rupiahs. This action resulted a penalty for Pricewaterhouse Coopers (PwC) because of their "reasonable with modification" opinion. In 8 January 2017, BPK RI in its public statement emphasized that PT. Jiwasraya's public auditor's opinion was an adverse opinion. The main reason is the company's Rp. 7 trillion loss. But it did not mean PT. Jiwasraya's claim about their profit is false (Saputra, 2020).

In 2018, the fraud case of PT. Garuda Indonesia was reported on online media, www.republika.co.id. The media reported that Public Accountant Office Tanubrata, Sutanto, Fahmi, Bambang, and Rekan, as an International Licensed Public Accountant, were the suspect of this fraud of financial licensed of PT. Garuda Indonesia. The violation of PT. Garuda Tbk were SA 315, SA 500, SA 560, and SA 700, which one of them was their claim on income receivables from PT Mahata Aero in the amount of 2,9 trillion. It was untimely claimed as income. As the result of this case, PT. Garuda Indonesia fired its directors and commissioners. PT. Garuda also had to pay fine which was given by OJK and Ministry of Finance. While Public Accountant Office Tanubrata, Sutanti, Fahmi, Bambang, and Rekan had to improve their Quality Control System of the Public Accountant Office and had to be re-reviewed by BDO International ltd (Surat No.S-210/MK.1PPPK/2019 tanggal 26 Juni 2019).

These two cases show that Auditor Committee should prevent Moral Hazzard by increasing the frequency of Auditor Committee's meeting in company. This could lead into the decreasing and preventing of company's problems. The impact of this action is quality increase in Financial statement and reduce the responsibility of External Auditor. By reducing External Auditor's job, the company can reduce the External Auditor.

CEO (Chief Executive Officer) is the person whom occupy the highest position in a company. CEO is the person who is responsible with the company's vision and mission (UU No.(40, 2007). Different with CFO, it is a position in an institution which responsible for the company's financial condition (Paulina et al., 2015). The changes in CEO and CFO is the measurements for the variable of executive turnover in this research. The 302 SOX section about the responsibility of CEO and CFO of public company are financial statement (Zulvinaa and Adharianib, 2019). As the result the turnover of CEO can affect who is going to be the auditor and its compensation. The appointment, dismissal, and turnover of the executive will be done through general meeting of shareholders. The information about the executive turnover can be viewed on the printed media (newspaper) or electronic media (radio and television). The market will give positive reaction on the CEO turnover routine in which the successor is from an internal company. Otherwise, if the person is coming from company's external, the public will give negative reaction (Bahtera, 2017).

Previously, some researchers have conducted a research regarding to CEO turnover. They focus on the impact of CEO turnover on profit management and market response (Adiasih and Kusuma, 2012; Bahtera, 2017; Effendi, 2020). While Aharony et al. (2015) 
found that contractual lawsuits effect on the increase of CEO turnover. The auditor fees is also affected by the CEO, research found that female CEO with higher minority ethnic tends to give higher salary (Harjoto et al., 2015). Meanwhile, research about CEO turnover's impact on Audit Fees has not been conducted by many researchers. Based on this fact, the author of this research feesl interested in that topic.

\section{THEORITICAL REVIEW}

Upper Echelon Theory. Li and Lo (2017) reveal that Upper Echelon Theory contains of top management or the board of directors and commissionaires in which they have to work together for the company survival, making long-term and short-term strategy, and making decisions together, including the policy of the amount of audit fee for external auditor.

Upper Echelon Theory firstly introduced by Hambrick and Mason (1984). It tells that the individual characteristic of the top management level will assign the decision of strategy. Upper Echelon Theory emphasize on the visible knowledge (cognitive) and invisible knowledge (Intelligence) of the top management level (Finkelstein et al., 1996), in this context, it means that the Chief Executive Officer (CEO). Related to inteligency, CEO have to be someone which has experiences, education, and good quality of social life. For the cognitive aspects, the top management can be seen from the speed aspect in responding out of control situation on the company and their skills in building strategy (Quttainah, 2015).

Chief Executive Office (CEO). CEO or known as President of Directors is someone who has the highest position in the company and who responsible for the vision and mission accomplishment of the company, Law number 40 Year 2007. As the result, the CEO turnover can influence the appointment and compensation of external audit. Appointment, dismissal, and CEO turnover activities can be set through General Meeting of Stakeholder (RUPS). The information about CEO turnover can be seen from various printed sources (newspaper) and electronic sources (radio and television).

CEO turnover can be differentiated into the process of turnover and the origin of CEO substitution. Based on the process, the CEO turnover is categorized into two groups, that are routine and nonroutine. Based on the origin of CEO turnover, there are two different types that are internal (inside) and external (outside) (Bahtera, 2017). The dismissal of the $\mathrm{CEO}$, if the board of directors fire the CEO, it is called force changeover. Mostly, the resignment of the CEO is based on the error suspect or determined and forced. Even though it is forced dismissal, it may be not as obvious as the regular dismissal. Otherwise the CEO can quit voluntary, such as a CEO who quit because of his age, which represent orderly transition as CEO (Huang et al., 2014). Usually, CEO is forced to quit when the performance of the company getting worse. Research has found that the role of board of directors in CEO departures; hence, the board of directors evaluate the performance of CEO by evaluating the company's performance relative to the board's expectation (Farrell and Whidbee, 2003; Puffer and Weintrop, 1991). 
Audit Committee. The policy from Bapepam-LK in which all companies have to form an audit committee, internal audit, and independent commissionaires of the company, as well as revealing the governance policy in annual report (www.ojk.go.id, 2012). The audit committee started to be popular in USA in 1930s. Then in 1970s, New York stock exchange (NYSE) obliged the existence of audit committee to record in stock exchange, and stated from that day, a lot of company started to form an audit committee (Wibowo, 2012).

Based on the current trend, Indonesia also started to follow International Standard alongside with the Good Corporate Governance guidelines in May 2002. Indonesian Audit Association (Ikatan Audit Indonesia/IKAI) defines the audit committee as a committee which works professionally and independently. It is formed by the board of commissionaires and has responsibilities to help and strengthen the function of the board of commissionaires (or board of supervisory) while carrying out the function of supervisory (oversight) over the financial reports, risks management, audit process, and corporate governance implementation in companies. The ability and skills of audit committee in financial field is the important characteristic in carrying out the audit committee operation activity. Audit committee who has skill in accounting and financial are the important factor to obstruct profit manipulation in company (Risty, 2015).

Audit Fees. Agoes (2012) states audit fee is the payment in the form of money or other things and other form of client in the audit engagement. The professional standard of public accountant section 240 point 1 about fee states that on the negotiation about audit service, the practitioners can suggest the amount of fee which is considered as worthy price.

In the process of getting the audit recompense (fee), public accountant have to do the stages of audit work, that are 1) Audit planning stages; understanding the client business, understanding the accounting cycles, assessment of internal control structure, determination of risks control, determination of materiality level, the making of audit program, and discussion of fraud by the management; 2) The stages of auditing process; examination of internal control, examination of substantive transaction, analytic procedure, and examination of detailed transaction; 3) Reporting stages; review the responsibility, reviewing events after the balance sheet date, assessment final evidence, evaluating conclusion, communication with management, and publishing the audit report.

Chief Executive Officer/Chief Finance Officer Turnover towards Audit Fees. The theory of Upper Echelon explains that top management level which contains members of board of directors and commissionaires have to make decisions for the sustainable company's future, and one of them is appointing external auditor and its fees. There are four reasons why the executive estimates the probability of detection and adjustment. First, Albrecht et al. (2018) states that the executive believes that probability of detection in the future is lower compared to moderate material misstatements. The executive predicts that misstatements can be fixed on the upcoming year from detection year. The executive recognize that they become aggressive but do not trust actual misstatements. Last, if it is being detected, the executive looks forward to convince the auditor that the misstatement is not the real one. he usually reduces the audit fees when the executive has accounting competence. For those whom has accounting competence in facing higher risk, they do not even raise the audit fees (Albrecht et al., 2018). It is possible that the problem in the 
company influences both CEO turnover and rising the audit fee as the response of the financial perception which raise the risks report. Succession of CEO which happen on the $\mathrm{CEO}$ turnover event can raise the risk of financial report, uncertain things which arise from the CEO succession as well as making the audit fee higher (Bills et al., 2017).

A research shows that there is no relation between ethnic diversity of Board of directors and the value of company, as the result $\mathrm{CEO} / \mathrm{CFO}$ turnover may not affect to the audit fees (Kesaulya and Febriany, 2019). Mitra et al. (2019) found that the audit fee is higher on the initial years of CEO service and late years of CEO service. It happens because the auditor inserts higher risk in the presence of higher profit management probability (Mitra et al., 2019). From the auditor point of view the situation of the initial years of CEO service becomes serious implication to evaluate as a possibility the risk of audit higher compared to the profit. It is potential to make financial misstatement risk and audit risk. To reduce the risk, auditor tends to increase the audit's effort and make the scope of audit through involving many professional staffs and increase the audit time. These two points aim to stop the audit risk at the acceptable level. The auditor can include premium risk into the audit fee to cover every obligation of ex-post litigation loss because it is not detected as the misstatement material on the audit process. The merger effect from this activity on the auditor section make the audit fee increases. While Zulvinaa and Adharianib (2019) shows female CFO gives impact on the company's value, but it does not work on the existence of female CEO. On the other side, CEO turnover affects company performance, in which it could reduce the workload of auditor and it can reduce the costs (Trisnantari, 2012). However, on the forced CEO turnover case, the company tends to pay higher for the audit fees compared to the company which has voluntary CEO turnover and no CEO turnover (Huang et al., 2014).

H1: CEO turnover affect positively to the external audit fees.

Audit Committee Number of Meeting towards Audit Fees. Agency theory explains that assymetric information can be reduces by the right corporate governance mechanism. The stronger audit committee, it relates with the reduction of audit fees. It happens because of the low risk assessment by the auditor. Eventhough, (Sukma and Bernawati, 2019) have found that audit committee meeting do not significantly affect audit quality with proxy audit fees. On the other situation, there is a possibility of the increasing of the audit fee if the committee requests the auditor to perform a high quality auditing process (Mitra et al., 2019). Otherwise, Sukaniasih and Tenaya (2016) states that the intensity of committee audit meeting seizes a lot of external auditor time by attending the meeting with audit committee. As the result of the time wastement, higher salary needs to be given to the external auditor.

H2: Audit committee meeting frequency positively impact the external audit fees.

Return on Assets (ROA) and Total Assets toward Audit Fees. In terms of control variable, Return On Assets and Total Assets variable are the variable being used as their position as determinant in research (Miah et al., 2020). Financial analysis, including financial ratio analysis, weakness analysis, and its relation in financial, helps in assessing invest management in the past and the future prospect. Financial performance ratio (ROA) is chosen because its mathematical calculation interrelates with the income statement, as 
well as its function to control company measurement size in which can asses the audit risk and contribution in audit fees determination. The increase or decrease of the company assets can control the impact of company's ability to pay the external auditor. The total assets reflect the company size.

Based on the hypothesis development, the conceptual framework is:

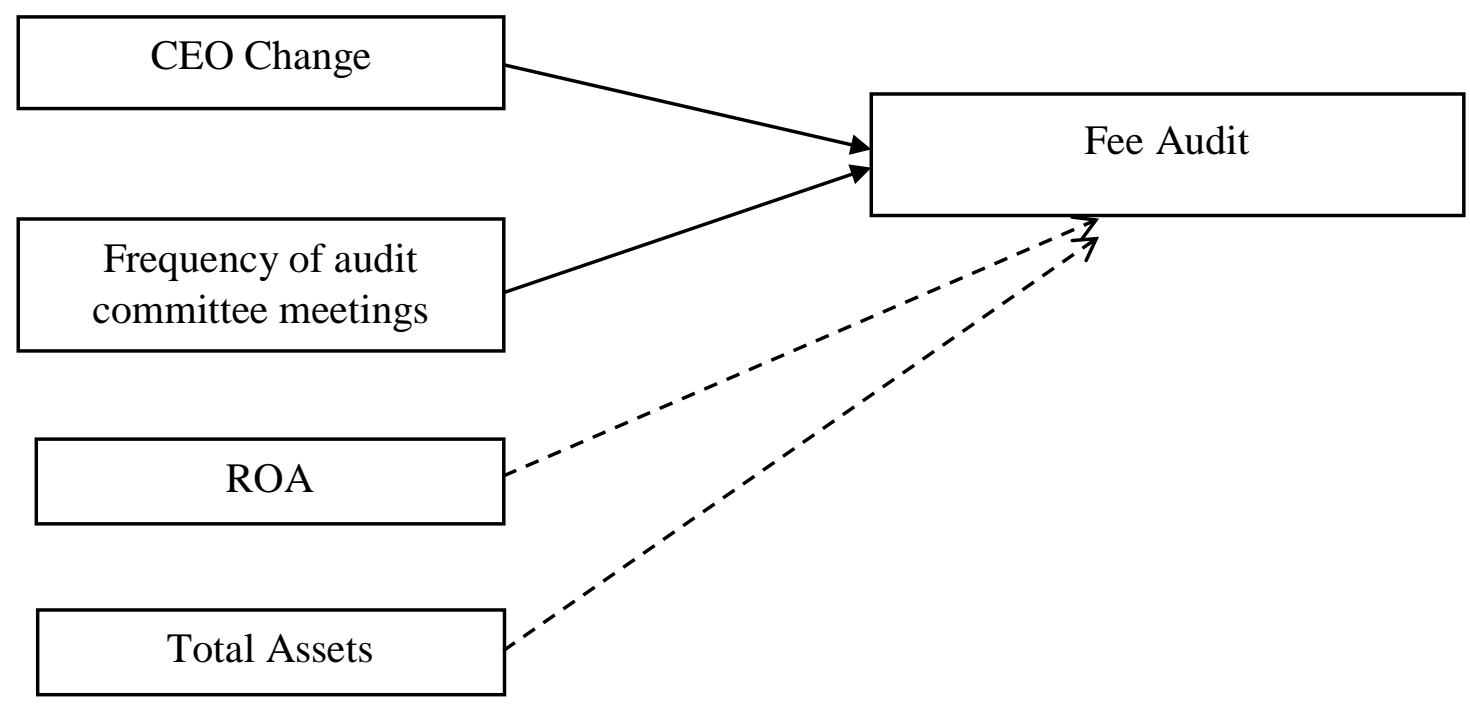

Figure 1. Conceptual Framework

\section{METHODS}

Population and Sample Research Method. This research is a quantitative research. The aim of this research is to assess the impact of independent variable to the dependent variable empirically. The independent variable of this research are CEO turnover and the frequency of audit committee's meeting, while the dependent variable is the audit fees. This research use Return on Assets (ROA) and Total Assets as the variable control. The population of this research is all manufacture company which is registered on BEI in 2018-2019. The sample is chosen through Purposive Sampling, in which the writer chooses the sample which can fulfill the criteria and the aims of this research.

Types and Sources of Data. The type of data which is used in this research is the secondary data. It is collected through documentation technique. In this research the author uses the data in the form of company's financial statements and annual reports. The company's financial statement which is used only published by the company in the year 2018 to 2019. The source of the data is taken from Indonesia Stock Exchange (www.idx.co.id) and the respective website.

\section{Operational Definition and Variable Measurement}

CEO Change. The CEO turnover is the changing of company's leader, both CEO and CFO within a year of service. Section $302 \mathrm{X}$ about responsibility in corporate, the person in charge 
of financial statement are CEO and CFO (Zulvinaa and Adharianib, 2019). The measurement of the CEO turnover variable uses dummy variable, in which 0 for the company which do not held CEO turnover; and 1 for the company which the company do not have CEO turnover.

Audit Committee Number of Meetings. The frequency of audit committee meeting is the number of committee audit meeting a year with board of commissionaires, board of director, external auditor, or the head of each department. The aim of the meeting is to assess the effectivity of company's internal control or the occasion related to audit fees determination and the appointment of external auditor. The information about the audit committee's meeting frequency can be seen on the audit committee's profile in annual report.

Audit Fees. Agoes (2012) states that audit fee is the compensation in the form of money or other things which is given to or received from client or the other party for the engagement with client or other party. The standard of professionality of public accountant section 240 point 1 about fees tells that the public accountant can propose the amount of the compensation regarding to the professional services while doing the negotiation. The information abour audit fees can be found in the capital market supporting institutions in the annual report.

Return on Assets (ROA) and Total Assets. Return on Assets (ROA) is a ratio which counts the level of return on the total assets which is owned by the company. The measurement through dividing EAT (Earning after tax) by total assets based on research. The total assets is measured through summing the current assets and fixed assets in companies in the yearend balance (Miah et al., 2020). Afterwards the total assets will be converted to natural logarithm to avoid bias from the total assets.

The examination is done by multiple linear regression analysis method and before the regression analysis, classic assumption test will be performed first. The classic assumption test helps to reveal whether the data can be used for the examination process. The research population is all the manufacture company which is registered in BEI in 2018-2019, while the sample of the research will use some conditions: (1) Manufacture company registered in BEI (Indonesia Stock Exchange). (2) Manufacture company which publish annual report and can be obtained. (3) Manufacture company which reveals the audit fees data. (4) Manufacture company which suffer no losses.Based on the criteria, there are 103 manufacture company in 2018-2019 will be processed. 
Table 1. Sampling

\begin{tabular}{l|c|c|c}
\hline \multicolumn{1}{c|}{ Sample selection } & $\mathbf{2 0 1 8}$ & $\mathbf{2 0 1 9}$ & Total \\
\hline $\begin{array}{l}\text { Manufacture company } \\
\text { registered in BEI }\end{array}$ & 168 & 169 & 337 \\
$\begin{array}{l}\text { AR is not found on the } \\
\text { website }\end{array}$ & $(17)$ & $(15)$ & $(32)$ \\
$\begin{array}{l}\text { Company which does not } \\
\text { reveal the audit fees data }\end{array}$ & $(78)$ & $(67)$ & $(145)$ \\
$\begin{array}{l}\text { The company suffered a loss } \\
\text { in the research year }\end{array}$ & $(28)$ & $(29)$ & \\
$\begin{array}{l}\text { Final Sampling (Net } \\
\text { Sampling) }\end{array}$ & 45 & 58 & 103 \\
\hline
\end{tabular}

Equations. The model of research to examine the impact of independent variable towards dependent variable are:

LnAF $=\alpha+\beta 1$ CEOChange $+\beta 2$ ACMeetings $+\beta 3$ ROA $+\beta 4$ LnASSETS $+\mathrm{e}$

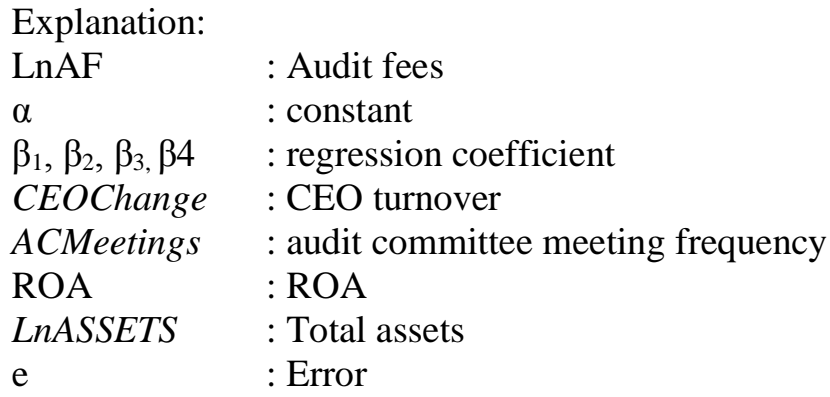

\section{RESULTS}

The result of examination contains of descriptive statistic, classical assumption test (normality test, heteroscedasticity test, and multicollinearity test), regression analysis, $t$ test, $\mathrm{F}$ test, and coefficient of determination $\left(\mathrm{R}^{2}\right)$.

\section{Descriptive Statistics}

Table 2. Descriptive Statistics

\begin{tabular}{|c|c|c|c|c|c|}
\hline & $\mathbf{N}$ & Minimum & Maximum & Mean & Std. Deviation \\
\hline LnAsset & 103 & 25,80 & 32,26 & 28,5779 & 1,35704 \\
\hline $\mathrm{ROA}$ & 103 &, 0002 & ,4666 & ,070922 & ,0859254 \\
\hline ACMeet & 103 & 3,00 & 32,00 & 6,6990 & 5,26705 \\
\hline LnAFees & 103 & 18,47 & 22,50 & 20,3000 & ,96875 \\
\hline
\end{tabular}




\begin{tabular}{ll|l|l|l|l}
\hline CEOChange & 103 &, 00 & 1,00 &, 3495 &, 47915 \\
\hline Valid N (listwise) & 103 & & & & \\
& & & & & \\
\hline
\end{tabular}

Source: Data olah SPSS (2020)

Based on the table above, CEOchange has 0 minimum score and 1 maximum score as well as mean of 0,34 . While ACMeet has minimum score of 3, maximum score of 32, and mean by 6.699. LnAFEES variable has minimum score of 18,47 , maximum score of 22,50 , and mean of 22,3000. ROA variable has minimum score of 0,0002 with maximum score of 0,4666 and mean of 0,70922 . The LnAset variable has minimum score of 25,80 , maximum score of 32,26, and mean of 28,5779. Before doing regression analysis, classical assumption test will be conducted with the result as represented below:

\section{Classical Assumption test}

Normality test. Based on the examination, the amount of Kolmogorov-Smirnow is 0,077 with signification of 0,138 . The signification 0,138 is higher than $a=0,05$. It can be assumed that the data is normally distributed, like described at Table 3 below:

Table 3. One-Sample Kolmogorov-Smirnov Test

\begin{tabular}{llr} 
& & \multicolumn{1}{c}{$\begin{array}{c}\text { Unstandardized } \\
\text { Residual }\end{array}$} \\
\hline $\mathrm{N}$ & & 103 \\
\hline Normal Parameters & Mean &, 0000000 \\
\cline { 2 - 3 } & Std. Deviation &, 62565724 \\
\hline Most Extreme Differences & Absolute &, 077 \\
\cline { 2 - 3 } & Positive &, 076 \\
\cline { 2 - 3 } & Negative &,- 077 \\
\hline Test Statistic & &, 077 \\
\hline Asymp. Sig. (2-tailed) & &, $138^{c}$ \\
\hline
\end{tabular}

Source: Processed Data (2020)

Multicollinearity test. The result of multicollinearity test show that multicollinearity does not appear on the regression model. This result is shown through tolerance score $>0,10$ and VIF<10. The variable of CEOChange, ACMeet, ROA, Total Assets has tolerance score 0,907;0,929;0,937;0,811 and VIF score 1,$102 ; 1,076 ; 1,067 ; 1,232$, described at Table 4 below:

Table 4. Coefficients ${ }^{\mathrm{a}}$

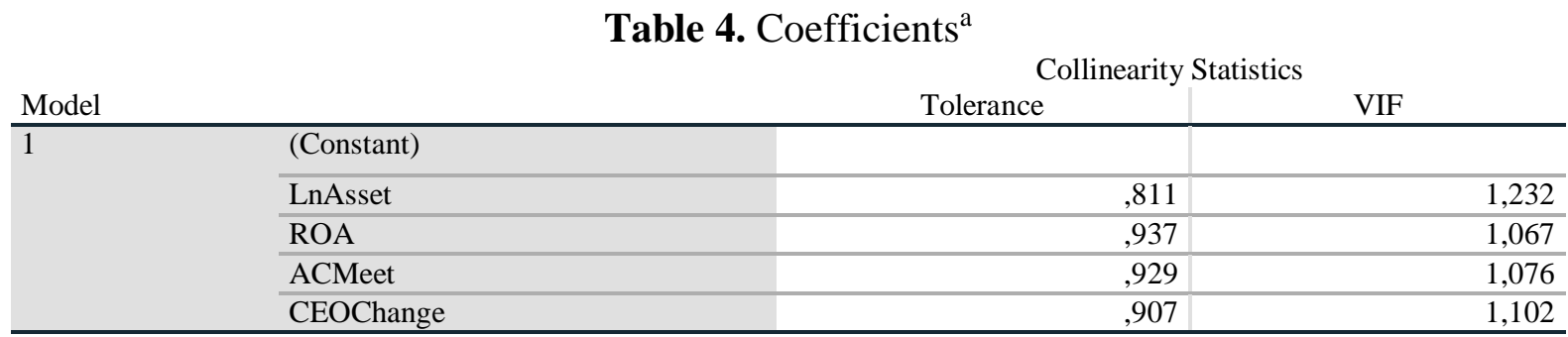


Heteroscedasticity test. The result of heteroscedasticity examination with scatterplot shows the spread of the data which has meaning that the data are free from heteroscedasticity.

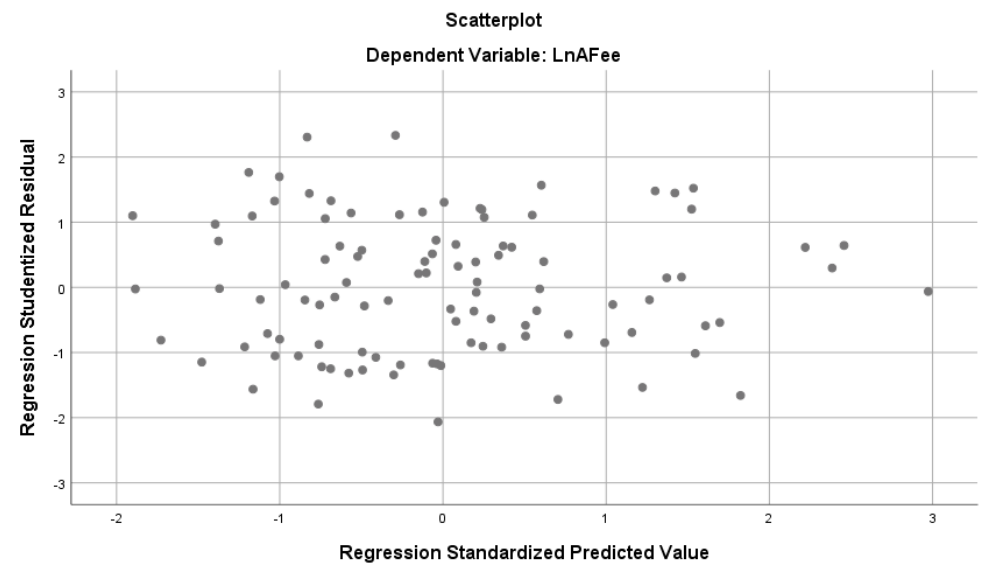

Figure 2. Heteroscedasticity Test

Regression Analysis. After the classical assumption test is done, the result is processed with multiple linear regression analysis, that consist of determination coefficient, F test, and $\mathrm{t}$ test and the result as represented in the table below:

\section{The Coefficient of Determination $\left(\mathbf{R}^{2}\right)$}

Table 5. The coefficient of determination $\left(\mathrm{R}^{2}\right)$

\begin{tabular}{|c|c|c|c|c|c|}
\hline \multicolumn{6}{|c|}{ Model Summary } \\
\hline Model & $\mathrm{R}$ & R Square & $\begin{array}{l}\text { Adjusted R } \\
\text { Square }\end{array}$ & $\begin{array}{l}\text { Std. Error of the } \\
\text { Estimate }\end{array}$ & Durbin-Watson \\
\hline 1 &, $763^{\mathrm{a}}$ & ,583 & ,566 & ,63830 & 1,861 \\
\hline
\end{tabular}

Source: Processed data (2020)

The score of $\mathrm{R}^{2}$ shows that the CEOChange, ACMeet, ROA, and LnAset variable explain the changes against its dependent variable (Audit Fees) in the number of 56,6\%, while the other $43,4 \%$ is influenced by the other factors outside the chosen variable.

\section{F simultant test}

Table 6. F Simultant Test

\begin{tabular}{|c|c|c|c|c|c|c|}
\hline \multicolumn{7}{|c|}{ ANOVA $^{a}$} \\
\hline Model & & Sum of Squares & df & Mean Square & $\mathrm{F}$ & Sig. \\
\hline \multirow[t]{3}{*}{1} & Regression & 55,798 & 4 & 13,949 & 34,238 &, $000^{\mathrm{b}}$ \\
\hline & Residual & 39,928 & 98 & ,407 & & \\
\hline & Total & 95,725 & 102 & & & \\
\hline
\end{tabular}

Source: Processed Data (2020) 
Based on the result, as it is seen that the F score is 34,238 with significance of 0,000 . This result shos that the model is qualified to be used. According to the significance, this research results $0,000<0,050$. Therefore, it can be said that there is effect of CEOChange, Audit committee meeting frequency, ROA, and total assets against external audit fees.

Table 7. $t$ Test

\begin{tabular}{|c|c|c|c|c|c|c|}
\hline \multicolumn{7}{|c|}{ Coefficients ${ }^{a}$} \\
\hline \multirow{2}{*}{\multicolumn{2}{|c|}{ Model }} & \multicolumn{2}{|c|}{ Unstandardized Coefficients } & \multirow{2}{*}{$\begin{array}{c}\text { Standardized } \\
\text { Coefficients } \\
\text { Beta }\end{array}$} & \multirow[b]{2}{*}{$\mathrm{t}$} & \multirow[b]{2}{*}{ Sig. } \\
\hline & & B & Std. Error & & & \\
\hline \multirow[t]{5}{*}{1} & (Constant) & 7,427 & 1,436 & & 5,173 & ,000 \\
\hline & LnAsset & , 440 &, 052 & ,617 & 8,519 &, 000 \\
\hline & ROA & 3,622 & ,760 &, 321 & 4,767 & 000 \\
\hline & ACMeet & ,013 & ,012 & 069 & 1,025 & ,308 \\
\hline & CEOChange &,- 161 & , 138 &,- 080 & $-1,162$ & ,248 \\
\hline
\end{tabular}

Source: Processed Data (2020)

Based on t test above, it shows that CEOChange variable is on significance of $0,248>0,05$ which coefficient score $-0,161$. This result shows that there is no effect on the CEO turnover on external audit fees ( $\mathrm{H}_{0}$ Accepted). The variable of ACMeet has significance of $0,308>$ 0,05 with coefficient of 0,013 . This result means that the audit committee meeting frequency has no effect on external audit fees $\left(\mathrm{H}_{0}\right.$ Accepted). Return on Assets variable is on significance number of $0,000<0,05$ with coefficient of 3,622. This result show that there is positive influence on Return on Assets to the external audit fees. The LnAssets Variable is on the significant number of $0,000<0,05$ with coefficient of 0,440 . This result show that there is positive effect of Total Assets on external audit fees.

From the result of regression analysis above, regression model which produced is:

$$
Y=7,427-0,161 X 1+0,013 \times 2+3,622 \times 3+0,440 X 4+€
$$

\section{Explanation:}

(1) Constanta $(\alpha)$ is 7,427 . This means that if the independent variable is equal to 0 . Thus the audit fee is 7,427. (2) The coefficient value of CEOChange is -0.161 which indicates that if there is a change in CEO (X1), it will result in a decrease in audit fees of 0.161 based on the assumption that the other variables are constant. (3) The coefficient value of AC Meetings is 0.013, indicating that if the Audit Committee Meeting Frequency variable (X2) is increased. That way it can also have an impact on an increase in audit fees of 0.013 based on the assumption that the different variables are constant. (4) The ROA coefficient value is 3,622 which shows if the variable of ROA (X3) is increased. That way it can also have an impact on an increase in audit fees of 3,622 based on the assumption that the different variables are constant. (5) The ASSETS coefficient value is 0.440 , it shows if the variable of ASSETS (X4) is increased. That way it can also have an impact on an increase in audit fees of 0.440 , based on the assumption that the different variables are constant. 


\section{DISCUSSION}

CEO Turnover towards Audit Fees. Based on the statistic test, CEO turnover has two significance, that is 0,248 and coefficient of regression of $-0,161$. The theory of Upper Echelon explain that the board of directors and commissionaires have to work together to make decisions. It means this theory is not applicable on manufacture company in Indonesia. Bills et al. (2017) on his research found that the audit fee is increasing after the succession of the new CEO. However, on his research is also stated that the increase of audit fees disappear as the time when the new CEO who is not the heir of the company stays longer in the company. But, it is different with (Huang et al., 2014) and (Mitra et al., 2019) who found that CEO turnover or CEO Tenure have significance on the audit fees. This possibility happens on the appointment of external auditor. The auditor has been reconsidered the possibility which will appear in the future, as well as the auditor confidents that the performance will not be influenced by CEO turnover as it is common in company environment. Auditor does not consider the power of CEO/CFO seriously on its risk assessment. The CEO turnover does not increase the risks of materials misstatement by the client as well as it does not influence the audit fees. As the result, there is no effect of CEO turnover on audit fees.

Audit Committee Meeting Frequency towards Audit Fees. Upper Echelon theory explain that the board of director and commissionaires have to make decision together, one of them is related to external auditor. It reveals that the theory is not in accordance with manufacture company in Indonesia because the meeting frequency of audit committee does not affect audit fees. It means, in the meeting between audit committee and external auditor is not limited to the negotiation of audit fee, but also discussion other topics such as inspection, understanding the internal control, and other topic which does not related to audit fee. Beside that, the meeting which is done by the audit committee does not align the relationship between the agent and principal and become the opposition of agency theory. Based on statistic test, the frequency of audit committee meeting has significance of 0,308 and coefficient of regression of 0,013 . This result is different compared to previous study which found that the audit committee meeting frequency has negative significance towards audit fees (Wibowo, 2012). However, (Suryanto et al., 2018) found similar result that audit committee meeting frequency has no significance on external audit fees. The amount of audit committee which attend the meeting dos not increase or decrease the sceptics of auditor. Even though there is possibility of addition or reduction of risks in the company. This result explains that between the audit committee and external auditor, both of them are not related. Since they are different institutions, every activities or decisions which made by audit committee will not affect the function of external auditor as well as the frequency of audit committee meeting will not affect external audit fees.

Return On Assets (ROA) and Total Assets towards Audit Fees. Based on statistic test, return on assets (ROA) and total assets has significance of 0,000 and coefficient of regression of 0,321 and 0,617 . This data means there is significance. This result showing similarities with Miah et al. (2020) which found that the result of total assets has positive influence towards external audit fees, but the difference appears on the coefficient of ROA in which has negative result. 
Based on the result above, the ROA and Total Assets become the indicators which influence the level of audit fee. Higher profit make the company has opportunity cost to use its retained earnings. This opportunity can be used to improve the quality of audit of financial statement which will result on the audit fees increase. This explanation shows that high ROA become the focus of external auditor, the higher company's profit the higher audit fees will be. Likewise, the total asset, the higher total assets the scope of audit by the external auditor become wider. As the result, the audit fees will be raising.

\section{CONCLUSION}

This research is proven that CEO turnover and audit committee meeting frequency does not influence the external audit fees. This situation represents that for manufacture company in Indonesia, CEO turnover related to the transfer of rights and obligation in which external auditor have to be careful with the possibility of profit management practices and audit procedures. Even though the supervision by the audit committee is not effective, the auditor does not include the risk over CEO turnover in giving audit cost. The implication for auditor is the auditor should accept klien with high ROA and Total Aset because it must have high-risk and high probability of earning management, so it results higher audit fees. Company management does not need to worry about CEO turnover and the number of audit committee meeting. They will not influence the audit fees. In fact, ROA and total assets of the company are the factor of the changes in audit fees. The limitation which appears while conducting the research is the difficulty of finding audit fees data in annual report. As the result, the effect against regulator is the regulator have to enforce the rules to reveal the audit fee. Last, for the upcoming research, this study is expected to help finding other proxy like Big4 or Non-Big 4 KAP and opinion result.

\section{REFERENCES}

Adiasih, P. and I. W. Kusuma (2012). "Manajemen Laba Pada Saat Pergantian CEO (Dirut) Di Indonesia." Jurnal Akuntansi dan Keuangan 13(2): 67-79.

Aharony, J., C. Liu and A. Yawson (2015). "Corporate litigation and executive turnover." Journal of Corporate Finance 34: 268-292.

Albrecht, A., E. G. Mauldin and N. J. Newton (2018). "Do auditors recognize the potential dark side of executives' accounting competence?" The Accounting Review 93(6): 128.

Bahtera, N. T. (2017). "Analisis Reaksi Pasar Terhadap Pengumuman Pergantian Chief Executive Officer (CEO)." The Indonesian Journal of Applied Business 1(1): 14-29.

Bills, K. L., L. L. Lisic and T. A. Seidel (2017). "Do CEO succession and succession planning affect stakeholders' perceptions of financial reporting risk? Evidence from audit fees." The Accounting Review 92(4): 27-52.

Chandra, M. O. (2016). "Pengaruh good corporate governance, karakteristik perusahaan dan ukuran Kap terhadap fee audit eksternal." Jurnal Akuntansi Bisnis 13(26): 174-194.

Effendi, B. (2020). "Profesional Fee, Pergantian Chief Executive Officer (CEO), Financial Distress dan Real Earnings Management." Jurnal Ilmiah Akuntansi dan Bisnis 4(2): 105-120. 
Finkelstein, S., D. Hambrick and A. A. Cannella (1996). "Strategic leadership." St. Paul: West Educational Publishing.

Harjoto, M. A., I. Laksmana and R. Lee (2015). "The impact of demographic characteristics of CEOs and directors on audit fees and audit delay." Managerial Auditing Journal.

Huang, H.-W., R. J. Parker, Y.-C. A. Yan and Y.-H. Lin (2014). "CEO turnover and audit pricing." Accounting Horizons 28(2): 297-312.

Indonesia. (2007). Undang-Undang Republik Indonesia Nomor 40 Tahun 2007 tentang Perseroan Terbatas.

Kesaulya, F. A. and N. Febriany (2019). "Pengaruh Diversitas Kebangsaan Board of Director dan Kepemilikan Blockholders terhadap Nilai Perusahaan: Studi pada Perusahaan Publik di Indonesia." Kompartemen: Jurnal Ilmiah Akuntansi 16(2).

Miah, M. S., H. Jiang, A. Rahman and W. Stent (2020). "Audit effort, materiality and audit fees: evidence from the adoption of IFRS in Australia." Accounting Research Journal.

Mitra, S., H. Song, S. M. Lee and S. H. Kwon (2019). "CEO tenure and audit pricing." Review of Quantitative Finance and Accounting: 1-33.

Paulina, Jayalaksmi, Winoto and Supatmi (2015). "Pengaruh Diversitas Kebangsaan Board of Director Terhadap Nilai Perusahaan. UKSW." UKSW.

Quttainah, M. A. (2015). "Upper Echelon Theory: Role of Community and Strategy." Expert Journal of Business and Management 3(2).

Saputra, R. P. d. D. A. (2020). SIARAN PUBLIK ATAS PERMASALAHAN PT ASURANSI JIWASRAYA, www.iapi.or.id.

Sukma, P. and Y. Bernawati (2019). "The Impact of Audit Committe Characteristics on Audit Quality." Jurnal Akuntansi 23(3): 363-378.

Suryanto, R., S. A. D. Siskawati and H. Sofyani (2018). "Pengaruh Struktur Corporate Governance Dan Risiko Perusahaan Terhadap Fee Audit." JRAK: Jurnal Riset Akuntansi dan Komputerisasi Akuntansi 9(1): 102-127.

Trisnantari, A. N. (2012). "Pengaruh Corporate Governance pada hubungan pergantian chief executive officer dengan kinerja perusahaan." Jurnal Ilmiah Akuntansi dan Humanika 1(2).

Wibowo, R. H. (2012). "PENGARUH STRUKTUR GOVERNANCE DAN ETNISITAS TERHADAP FEE AUDIT (STUDI PADA PERUSAHAAN YANG LISTING DI INDEKS KOMPAS 100." Jurnal Ilmiah Akuntansi dan Humanika 2(1).

www.ojk.go.id (2012). "PEMBENTUKAN DAN PELAKSANAAN KERJA KOMITE AUDIT."

Zulvinaa, D. and D. Adharianib (2019). "Executives' Gender and Firm Value." International Journal of Innovation, Creativity and Change 7(5): 266-279. 